\title{
EFFICACY OF TAP BLOCK AND PLACEBO FOR PAIN IN PATIENTS UNDERGOING C- SECTION SURGERY
}

\author{
Usman Khalid, Kaukab Majeed, Maihmoona Yasmeen, Khalid Mehmood, Muhammad Ali Muazzam, Jawad Rehmani \\ Combined Military Hospital Quetta/National University of Medical Sciences (NUMS) Pakistan
}

\begin{abstract}
Objective: To compare efficacy of transversus abdominis plane block and placebo for pain in patients undergoing C-section surgery.

Study Design: Comparative cross-sectional study.

Place and Duration of Study: Department of Anaesthesiology, Combined Military Hospital Quetta, from Apr to Oct 2018.

Methodology: A sample size of 200 patients calculated by WHO calculator undergoing Elective C-section and of age 20-40 year were randomized in a double blind study to undergo transversus abdominis plane block or placebo group in two equal groups. Group A received block as placebo and group B with Bupivacaine. Results recorded and analysed there-after for conclusion.

Results: The mean age of patients in group A was $29.98 \pm 5.18$ years and in group B was $29.68 \pm 5.43$ years $(p-$ value $\leq 0.01)$. Majority of the patients $141(70.50 \%)$ were between 31 to 40 years of age. Out of 200 patients, 108 $(54.0 \%)$ were ASA I and $92(46.0 \%)$ were ASA II ( $p$-value $\leq 0.01)$. Mean body mass index was $25.20 \pm 2.28 \mathrm{~kg} / \mathrm{m}^{2}$ ( $p$-value $\leq 0.01$ ). Meantime for the first analgesia in the patients undergoing elective C-section in group A (placebo group) was $4.96 \pm 1.44$ hours while in group B (transversus abdominis plane block group) was $11.24 \pm 1.83$ hours $(p$-value $\leq 0.01)$.

Conclusion: This study concluded that meantime for the first analgesia was found longer in Transversus Abdominis plane block for post-operative pain management in patients undergoing elective C-section.
\end{abstract}

Keywords: Bupivacaine, Caesarean section, Transverse adominis plane block.

This is an Open Access article distributed under the terms of the Creative Commons Attribution License (http://creativecommons.org/licenses/by/4.0), which permits unrestricted use, distribution, and reproduction in any medium, provided the original work is properly cited.

\section{INTRODUCTION}

Pain after caesarean section is usually described as moderate to severe by most patients and failure to adequately treat may affect mother baby bonding, care of baby and breastfeeding. In order to relieve pain after surgery, local anesthetic infiltration (LAI) is commonly used as a traditional method ${ }^{1}$. Opioids analgesics are also commonly used for pain relief in the immediate post operative period ${ }^{2,4}$. Use of opioids in the immediate post operative period is associated with a number of side effects ${ }^{3}$. Postoperative pain and incidence of opioids related side effects can be effectively reduced by transversus abdominis plane block ${ }^{1-3}$. Ultrasound-guided transversus abdominis plane block is a newer technique for

Correspondence: Dr Muhammad Ali Muazzam, Combined Military Hospital, Quetta Pakistan

Received: 17 Apr 2019; revised received: 11 Dec 2019; accepted: 17 Dec 2019 postoperative analgesia compared to other conventional techniques ${ }^{4-6}$.

Transversus abdominis plane block was first described by Rafi in 20017. It is a desired anatomic location from where four peripheral nerves subcostal; ilioinguinal, iliohypogastric, and genitofemoral nerves pass through the abdominal wall between the transversus abdominis and the internal oblique. Transversus abdominis plane block is actually a field block in which local anesthetic is administered within an anatomical plane of the surgical site ${ }^{4}$ between transversus abdominis and internal oblique muscle ${ }^{7}$. Pain associated with an abdominal incision can be effectively reduced by transverses abdominis plane block which blocks neural afferents in the abdominal wall between T6 and L13-5. It is usually performed in a supine position. Transversus abdominis plane block provides both distal as well as localized field effects ${ }^{8}$. 
Ultrasound guided TAP block provides better pain relief after laparoscopic cholecystectomy compared to port site infiltration ${ }^{10}$ and prolongs the time for first analgesic request in the early post-operative period ${ }^{9}$. The cost-effectiveness of anesthesia has also been found to be better in patients receiving TAP block ${ }^{11}$.

The study was being conducted in our center for the first time to evaluate the benefits of TAP block in comparison to those not receiving TAP block so that it can be practiced, if found beneficial, for the better pain relief.

\section{METHODOLOGY}

After approval of hospital ethics committee, this comparative cross-sectional study was conducted in the Department of Anaesthesiology, Combined Military Hospital, Quetta, from April 2018 to October 2018. The study consisted of 200 patients with 100 patients in each group. The sample size was calculated by using WHO sample size calculator with following assumptions, mean time required of 1st analgesia in placebo group was $5.57 \pm 1.7312$ and in TAP block group= $12.25 \pm 2.6112)$.

A total of 200 patients undergoing Elective C-section and of age 20-40 year were randomized in a double blind study to undergo TAP block or placebo group in two equal groups. Patients belonging to ASA I and II requiring elective caesarean via pfannentiel incision were included. Patient of $<50 \mathrm{~kg}$ or $>100 \mathrm{~kg}$ weight, with any contraindication to spinal anaesthesia or who were unable to understand numericrating scale were excluded. Group A received block as placebo and group B with bupivacaine. Results recorded and analysed thereafter for conclusion. Patients who were unable to understand the Numerical Rating score and contra indication for spinal anesthesia were excluded. Analgesic in the form of injection Nalbuphine was dispensed, strictly on first demand by the patient using NRS and the time for first analgesic demand was noted.

Written informed consent was obtained from each patient included in the study. After explaining the purpose of the study and the advantages and disadvantages of each technique used. Patients were selected from Gynae opd and preanesthesia clinic, randomly allocated to one of the two groups based on random number tables generated by a computer.

The group A patients who received TAP block with $22 \mathrm{G}$ spinal needle with $10 \mathrm{ml}$ normal saline bilateral (placebo) and group Bpatients who received TAP block with $22 \mathrm{G}$ spinal needle with $0.25 \%$ bupivacaine $10 \mathrm{ml}$ bilateral.

Spinal Anaesthesia was given by the same consultant having 5 years of experience, at least, and all patients have undergone the standard $\mathrm{C}$ section from the same Obstretician. All patients received. Metoclopramide $(10 \mathrm{mg})$ I.V. Each patient received spinal anesthesia with $1.5 \mathrm{ml}$ of $0.75 \%$ hyperbaric bupivacaine from the same manufacturer.

After surgery, each patient of group A received Ultrasound guided TAP Block with Placebo and group $B$ received Ultrasound guided TAP Block with Bupivacaine by a researcher who is kept blind with the administration of drug or Placebo. In all patients surgical incision was covered with dressing and patient was shifted to Post Anaesthesia Care Unit (PACU) and monitored for postop pain for 24 hours.

Data were analyzed using Statistical Package for Social Science (SPSS) version 23. For quantitative variables like age, BMI, duration of surgery, Number of previous C-sections and time required for the first analgesia were presented as mean and standard deviation (SD). For qualitative variables like ASA status, was measured as frequency and percentages by using independent t-test if data show normal distribution, for nonparametric data Mann- Whitney U-test keeping $p$-value $\leq 0.05$ as significant.

Effect modifier like age, body mass index, duration of surgery, number of previous C-sections and ASA status were controlled through stratification. Post-stratification independent $\mathrm{t}$ test, for non-parametric data, Mann-Whitney Utest was applied to keep these values $<0.05$ as significant. 


\section{RESULTS}

A total number of 200 patients undergoing Elective Cesarean Section were randomized in a double blind study to undergo TAP block or placebo trial. The age range in this study was from 20-40 years with a mean age of $29.76 \pm 5.22$ years. The mean age of patients in group A was $29.98 \pm 5.18$ years and in group B was $29.68 \pm 5.43$ years $(p$-value $<0.01)$. Majority of the patients 141 $(70.50 \%)$ were between 31 to 40 years of age.

Out of 200 patients, $108(54.0 \%)$ were ASA I and $92(46 \%)$ were ASA II ( $p$-value $\leq 0.01)$. Mean duration of surgery was $30.36 \pm 6.43$ minutes. Mean BMI was $25.20 \pm 2.28 \mathrm{~kg} / \mathrm{m}^{2}(p$-value $<0.01)$ andmean number of previous cesarean section was $1.32 \pm 1.08$.

Mean time duration for first analgesia requirement in patients of elective C-section in group A (placebo group) was $4.96 \pm 1.44$ hours while in group B (TAP block group) was $11.24 \pm 1.83$ hours ( $p$-value <0.01). Stratification of time for the first analgesia with respect to age groups and ASA status is shown in (table-I \& II) which sho-

Table-I: Stratification of time for the first analgesia with respect to age groups $(n=100)$.

\begin{tabular}{l|c|c|c}
\hline $\begin{array}{l}\text { Age of } \\
\text { Patients } \\
\text { (Years) }\end{array}$ & $\begin{array}{c}\text { Group A } \\
\text { Time for the } \\
\text { First Analgesia } \\
\text { (mins) } \\
\text { Mean } \pm \text { SD }\end{array}$ & $\begin{array}{c}\text { Troup B } \\
\text { First Analgesia } \\
\text { (mins) } \\
\text { Mean } \pm \text { SD }\end{array}$ & $\begin{array}{c}p \text { - } \\
\text { value }\end{array}$ \\
\hline $20-30$ & $5.39 \pm 1.47$ & $10.65 \pm 1.84$ & $<0.01$ \\
\hline $31-40$ & $4.79 \pm 1.39$ & $11.71 \pm 1.77$ & $<0.01$ \\
\hline
\end{tabular}

Table-II: Stratification of time for the first analgesia with respect to ASA $(n=100)$.

\begin{tabular}{|c|c|c|c|}
\hline \multirow[b]{2}{*}{$\begin{array}{l}\text { ASA } \\
\text { Status }\end{array}$} & Group A & Group B & \multirow[b]{2}{*}{$\begin{array}{c}p- \\
\text { value }\end{array}$} \\
\hline & $\begin{array}{l}\text { Time for the } \\
\text { First Analgesia } \\
\text { (mins) } \\
\text { Mean } \pm \text { SD }\end{array}$ & $\begin{array}{l}\text { Time for the } \\
\text { First Analgesia } \\
\text { (mins) } \\
\text { Mean } \pm \text { SD }\end{array}$ & \\
\hline I & $5.04 \pm 1.45$ & $11.68 \pm 1.94$ & $<0.01$ \\
\hline II & $4.87 \pm 1.42$ & $10.80 \pm 1.60$ & $<0.01$ \\
\hline
\end{tabular}

wed a significant difference in the mean time for the first analgesia in all age groups and genders. Similarly, a statistically significant difference was found in the mean time for the first analgesia with respect to duration of surgery and BMI as shown in (table-III \& IV) respectively. Stratifi- cation of mean time for the first analgesia with respect to a number of previous cesarean section is shown in table- $\mathrm{V}$.

Table-III: Stratification of time for the first analgesia with respect to duration of surgery $(n=100)$.

\begin{tabular}{|c|c|c|c|}
\hline \multirow[b]{2}{*}{$\begin{array}{l}\text { Duration } \\
\text { of } \\
\text { Surgery } \\
\text { (minutes) }\end{array}$} & Group A & Group B & \multirow[b]{2}{*}{$\begin{array}{c}p- \\
\text { value }\end{array}$} \\
\hline & $\begin{array}{c}\text { Time for the } \\
\text { first analgesia } \\
\text { (mins) } \\
\text { Mean } \pm \text { SD }\end{array}$ & $\begin{array}{l}\text { Time for the } \\
\text { First Analgesia } \\
\text { (mins) } \\
\text { Mean } \pm \text { SD }\end{array}$ & \\
\hline$\leq 30$ & $4.92 \pm 1.52$ & $11.92 \pm 2.02$ & $<0.01$ \\
\hline$>30$ & $5.00 \pm 1.35$ & $10.53 \pm 1.28$ & $<0.01$ \\
\hline
\end{tabular}

Table-IV: Stratification of time for the first analgesia with respect to $\mathrm{BMI}(\mathrm{n}=100)$.

\begin{tabular}{l|c|c|c}
\hline \multirow{2}{*}{$\begin{array}{l}\text { BMI } \\
\left(\mathbf{k g} / \mathbf{m}^{2}\right)\end{array}$} & $\begin{array}{c}\text { Group A } \\
\text { Time for the } \\
\begin{array}{c}\text { First Analgesia } \\
\text { (mins) }\end{array}\end{array}$ & $\begin{array}{c}\text { Group B } \\
\text { Time for the } \\
\text { First Analgesia } \\
\text { (mins) } \\
\text { Mean } \pm \text { SD }\end{array}$ & $\begin{array}{c}p- \\
\text { value }\end{array}$ \\
\hline $19-24$ & $5.07 \pm 1.47$ & $10.61 \pm 1.87$ & $<0.01$ \\
\hline $25-29$ & $4.88 \pm 1.42$ & $11.72 \pm 1.65$ & $<0.01$ \\
\hline
\end{tabular}

Table-V: Stratification of time for the first analgesia with respect to a number of cesareansections $(n=100)$.

\begin{tabular}{l|c|c|c}
\hline $\begin{array}{l}\text { No. of } \\
\text { Caesarean } \\
\text { Section }\end{array}$ & $\begin{array}{c}\text { Group A } \\
\text { Time for the } \\
\text { first analgesia } \\
\text { (mins) } \\
\text { Mean } \pm \text { SD }\end{array}$ & $\begin{array}{c}\text { Group B } \\
\text { Fime for the } \\
\text { First Analgesia } \\
\text { (mins) } \\
\text { Mean } \pm \text { SD }\end{array}$ & $\begin{array}{c}p- \\
\text { value }\end{array}$ \\
\hline $0-1$ & $4.78 \pm 1.36$ & $11.45 \pm 2.05$ & $<0.01$ \\
\hline $2-3$ & $5.21 \pm 1.51$ & $10.98 \pm 1.47$ & $<0.01$ \\
\hline
\end{tabular}

\section{DISCUSSION}

Mannaging pain following caesarean section is challenging. The analgesic regimen should be effective, safe and devoid of side effects. Cesarean section is associated with moderate to severe pain. In effective pain management affects breastfeeding and childcare ${ }^{12}$, and the immobility resulting from pain is a risk factor of thromboembolism $^{13}$. The results of this study demonstrated that TAP block supplemented by placebo was effective in reducing severity of pain both at rest and on movement. Mean time for the first analgesia in patients undergoing elective C-section in group A (placebo group) was $4.96 \pm 1.44$ hours while in group B (TAP block group) was $11.24 \pm 1.83$ hours ( $p$-value 0.0001).

According to a study conducted by Belavy et al, in 2009, 50 women received TAP block with 
either placebo or ropivacaine after $\mathrm{C}$ - section and showed asubstantialdecrease in 48 hours pain scores, post-surgical consumption of morphine, and adverse effects ${ }^{14}$. Eslamian et al ${ }^{15}$, in 2012 also assessed the efficacy of TAP blockadein which Lower Visual Analogue Pain score was observed in patients of TAP group both at rest and during coughing.

Similarly, a study conducted by Mc Donnell et al, in 2008 using TAP block after cesarean delivery by the blind approach, with $1.5 \mathrm{mg} / \mathrm{kg}$ ropivacaine or normal saline on each side and revealed good analgesia by TAP block ${ }^{16}$.

Study by Cansiz et al, in 2015 of TAP block revealed that pain scores were lower and time of demand for the first analgesia was significantly longer in study groups compared to control (no drug) groups ${ }^{17}$. Study conducted by Chansoria et al in 2015 using $20 \mathrm{ml}$ of $0.375 \%$ ropivacaine reavealed reduction in mean VAS score ( $p$-value $<0.001$ ) and reduced opioids requirements ${ }^{18}$.

A systematic review and meta analysis ${ }^{19}$, by Abdallah et al, in 2012 concluded that pain score, consumption of analgesia, and PONV for $24 \mathrm{~h}$ were less as compared to the control group, receiving a placebo. Over recent years, there has been growing interestin regional nerve block techniques with promising results on efficacy, TAP block is a rela-tively new abdominal nerve block with excellent efficacy.

\section{CONCLUSION}

The analgesia was found longer in transversus abdominis plane (TAP) block post-operatively. So, we recommend that the TAP block may be used in patient undergoing cesarean section in order to lessen the morbidity of patients.

\section{CONFLICT OF INTEREST}

This study has no conflict of interest to be declared by any author.

\section{REFERENCES}

1. Yu N, Long X. Transversus abdominis-plane block versus local anaesthetic wound infiltration in lower abdominal surgery: a systematic review and meta-analysis of randomized controlled trials. BMC Anaesthesiol 2014; 14(1): 121-25.
2. De Oliveira Jr GS, Castro-Alves LJ, Nader A, Kendall MC. Transversus abdominis plane block to ameliorate postoperative pain outcomes after laparoscopic surgery: a meta-analysis of randomized controlled trials. Anaesth Analges 2014; 118(2): 454-63.

3. Johns N, O'neill S, Vent ham NT, Barron F, Brady RR, Daniel T. Clinical effectiveness of transversus abdominis plane (TAP) block in abdominal surgery: a systematic review and metaanalysis. Colorect Diseas 2012; 14(10): e635-42.

4. Mishriky BM, George RB, Habib AS. Transversus abdominis plane block for analgesia after Caesarean delivery: a systematic review and meta-analysis. Canad J Anaest/J Canad Anesth 2012; 59(8): 766-78.

5. Sharkey A, Finnerty O, Mc Donnell JG. Role of transversus abdominis plane block after caesarean delivery. Curr Opin Anaesth 2013; 26(3): 268-72.

6. McDonnell JG. Role of transversus abdominis plane block after caesarean delivery. Current Opinion Anaesthesiol 2013; 26(3): 268-72.

7. Saliminia A, Azimaraghi O, Babayipour S, Ardavan K, Movafegh A. Efficacy of transverse abdominis plane block in reduction of postoperation pain in laparoscopic cholecystec-tomy. Acta Anaesth Taiwan 2015; 53(4): 119-22.

8. Petersen P, Stjernholm PKV, Torup H, Hansen E, Mitchell A, Moeller A. The Beneficial Effect of Transversus Abdominis Plane Block after Laparoscopic Cholecystectomy in Day-Case Surgery: A Randomized Clinical Trial. Anesth Analg 2012; 115(3): 527-33.

9. Saliminia A, Azimaraghi O, Babayipour S, Ardavan K, Movafegh A. Efficacy of transverse abdominis plane block in reduction of postoperation pain in laparoscopic cholecystectomy. Acta Anaesthesiol Taiwan 2015; 53(4): 119-22.

10. Kokulu S, Baki E, Kaçar E, Bal A, Senay H, Ustün K, et al. Effect of Transversus Abdominis Plane Block on Cost of Laparoscopic Cholecystectomy. Anaesth Med Sci Monit 2014; 20(1): 2783-87.

11. Srivastava U, Verma S, Singh TK, Gupta A, Saxsena A, Jagar KD, et al. Efficacy of trans abdominis plane block for post cesarean delivery analgesia: A double-blind, randomized trial. Saudi J Anaesth 2015; 9(3): 298-02.

12. Leung AY. Postoperative pain management in obstetric anaesthesia-New challenges and solutions. J Clin Anesth 2004; 16(2): 57-65.

13. Gadsden J, Hart S, Santos AC. Post-caesarean delivery analgesia. Anesth Analg 2005; 101(1): S62-69.

14. Belavy D, Cowlishaw PJ, Howes M, Phillips F. Ultrasoundguided transversus abdominis plane block for analgesia after Caesarean delivery. Br J Anaesth 2009; 103(1): 726-30.

15. Eslamian L, Jalili Z, Jamal A, Marsoosi V, Movafegh A. Transversus abdominis plane block reduces postoperative pain intensity and analgesic consumption in elective caesarean delivery under general anaesthesia. J Anesth 2012; 26(2): 334-38.

16. Mc Donnell JG, Curley G, Carney J. The analgesic efficacy of transversus abdo-minis plane block after caesarean delivery: A randomized cont-rolled trial. Anesth Analg 2008; 106(2): 186-91.

17. Cansiz KH, Yedekci AE, Sen H, Ozkan S, Dagli G. The effect of ultrasound guided transversus abdominis plane block for caesarean delivery on postoperative analgesic consumption. Gulhane Med J 2015; 57(1): 121-24.

18. Chansoria S, Hingwe S, Sethi A, Singh R. Evaluation of transversus abdominis plane block for analgesia after caesarean section. J Recent Adv Pain 2015; 1(2): 13-17.

19. Abdallah FW, Halpern SH. Transversus abdominis plane block for postoperative analgesia after caesarean delivery performed under spinal anaesthesia? A systematic review and meta-analysis. Br J Anaesth 2012; 109(1): 679-87. 